Int. J. Agril. Res. Innov. Tech. 10(2): 54-58, December 2020 Available online at https://ijarit.webs.com DOI: https://doi.org/10.3329/ijarit.v10i2.51577 https://www.banglajol.info/index.php/IJARIT

\title{
Quality evaluation of commercially available instant mango drinks powder in local market of Bangladesh
}

\author{
M.R Badsha ${ }^{1}$, S. Akther ${ }^{1,2^{*}}$, J.S. Jothi ${ }^{1}$ and A. Sultana ${ }^{1}$ \\ Received 14 May 2020, Revised 4 August 2020, Accepted 24 December 2020, Published online 31 December 2020
}

\begin{abstract}
A B S T R A C T
The upward trend of consumption of processed food must not dim the demand of taking healthy and safe food among population. Thus, six popular commercial brands of instant mango drinks powder of Bangladesh were targeted to investigate some quality parameters (proximate compositions, mineral contents and bioactive compounds). Mineral contents and bioactive compounds of instant mango drinks powder were determined by using biochemical analyzer and UV-visible spectrophotometer, respectively. Results of proximate analysis showed that moisture content, ash content, fiber content, and carbohydrate content of different brands of instant mango drinks powder ranged from 0.21 to $0.25 \%, 0.45$ to $0.55 \%$, 0.10 to $0.40 \%$, and 98.83 to $99.21 \%$, respectively, whereas energy value ranged from 395.32 to $396.84 \mathrm{Kcal} / 100$. Sodium, potassium, calcium, chloride, phosphorus, iron and vitamin- $\mathrm{C}$ were also determined, which showed the significant different $(\mathrm{p}<0.05)$ values among different brands. Total anthocyanin content (TAC), Total flavonoid content (TFC), Total phenolic content (TPC), Antioxidant capacity were determined as bioactive compounds. Results of bioactive compounds analysis also showed that the samples were significantly different $(\mathrm{p}<0.05)$. Although, the quality varied from brand to brand, but all the samples could be good source of vitamin-C, carbohydrate and energy. Furthermore, health concerning issues can be improved by focusing the bioactive compounds of commercially available instant drinks powder.
\end{abstract}

Keywords: Bioactive compounds, Instant mango drinks powder, Minerals contents, Proximate composition.

\footnotetext{
${ }^{I}$ Department of Food Processing and Engineering, Chattogram Veterinary and Animal Sciences University (CVASU), Chattogram-4225, Bangladesh.

${ }^{2}$ Department of Food Technology and Rural Industries, Bangladesh Agricultural University, Mymensingh-2202, Bangladesh.

*Corresponding author's email: shireen_cvasu@yahoo.com (S. Akther)
}

Cite this article as: Badsha, M.R, Akther, S., Jothi, J.S. and Sultana, A. 2020. Quality evaluation of commercially available instant mango drinks powder in local market of Bangladesh. Int. J. Agril. Res. Innov. Tech. 10(2): 54-58. https://doi.org/10.3329/ijarit.v10i2.51577

\section{Introduction}

Fresh fruits are perishable and have limited shelf life. To prolong shelf life, various processing and preservation methods such as drying, chemical treatments and various packaging methods are used. Dehydration of mango juice into powdered particles gives a considerable reduction in volume and is an effective method of prolonging the shelf life (Mahendran, 2011). Transportation and storage costs would be reduced significantly when shipping the products to distant markets. Dried juice products today are used mainly as convenience foods and have long storage life at ordinary temperatures (Pap, 1995). Completely dried fruit powders are often used for making food products. Fruit powders less than $4 \%$ (wb) moisture content can be used to make candy, toffee, fudge and hard candy.
Mango is a popular fruit with excellent flavor, attractive color, and delicious taste with high nutritional value. Due to higher moisture content (85\%); it has very poor keeping quality and can't withstand any adverse climatic conditions during storage. Therefore, $30 \%$ of fruits have been getting spoilage every year (Thind et al., 2002). To overcome this post-harvest loss and to increase the shelf life, the surplus mango has to be processed into shelf stable products like sterilized pulp or dried flakes or powders for consumption (Saxena and Arora, 1997). Mango powder is generally being used in processing of certain food products like ice cream, mango fruit bar, mango cereal flakes, mango cake. Therefore, there is a great need to develop a non-caking and soluble/readily mixing mango flakes/powder (Akhter et al., 2010). 
Instant mango drink provides instant rehydration and instant freshness. It is mostly useful in summer duration. Mango drinks powder is a refreshing fruit flavored drink with minerals and vitamins (Chen et al., 2000). It makes a refreshing drink that releases extra energy and rejuvenates us (McIntyre, 2000). High energy drink powder when mixed with water creates an instant breakfast drink. Mango drinks powder may attract the attention of the consumers due to their palatability, attractive color, better flavor and taste.

The instant mango drinks powder mainly consists of natural mango powders, sweetening agent, color source, flavor source, thickening agent, anticaking agent, acid source, and additives, which make it desirable, appealing, appetizing, delicious, and nutritious for our health. The nutrient profiles help the consumer to understand clearly about the safe consumption of instant mango drink powder. Therefore, the objectives of this study were to evaluate some major quality parameters of commercial drinks powder in Bangladesh, such as proximate compositions, mineral contents, and bioactive compounds (phenolic content, flavonoid content, anthocyanin content, and antioxidant capacity).

\section{Materials and Methods}

\section{Collection of instant mango drinks powder}

The instant mango drinks powder of six different brands (coded with A, B, C, D, E and F) were bought from various local market in Chattogram, Bangladesh. Samples were coded to overcome the sampling biasness

\section{Place of experiment}

The samples were analyzed in the Department of Food Processing \& Engineering and Department of Physiology, Biochemistry \& Pharmacology at Chattogram Veterinary and Animal Sciences University (CVASU), Chattogram, Bangladesh.

\section{Proximate analysis}

The proximate composition of instant mango drinks powder was determined using methods described by Association of Official Analytical Chemists (AOAC, 2016). The samples were analyzed for moisture, ash, crude protein, and crude fat. Carbohydrate content was determined by difference. The energy value of the samples was determined by multiplying the protein content by 4 , carbohydrate content by 4 and fat content by 9 according to standard formula (Akpakpan and Akpabio, 2012). All analyses were performed in triplicate.

\section{Mineral and Vitamin-C analysis}

Preparation of samples for Mineral analysis was followed instructions as in Mustafa and Medeiros
(1985) with minor modifications. Mineral contents were determined by using biochemical analyzer (Humalyzer 3000). Commercially available biochemical kit (Randox $囚$ ) was used for biochemical assay. The quantity of the vitamin $\mathrm{C}$ contained in each sample was determined by titrimetric method (using 2, 6dichlorophenol indophenol dye) described by Najwa and Azrina (2017).

\section{Bioactive compounds of instant drinks mango powders}

Preparation of extracts for bioactive compounds were followed instructions as described by Unal et al. (2014). Total anthocyanin content (TAC) and Total phenolic content (TPC) of the instant mango drinks powder were determined according to the method described by Unal et al. (2014). Total flavonoid content (TFC) of the instant mango drinks powder was determined using the aluminum chloride colorimetric method described by Chang et al. (2002). Antioxidant capacity of the instant mango drinks powder was determined using DPPH assay as described by Azlim Almey et al. (2010).

\section{Statistical tools to be used for data analyses}

Statistical analysis was performed by using MS Excel 2013 and Statistical Package for Social Science (SPSS $16^{\text {th }}$ version). Values are expressed as means \pm standard deviation (SD). One-way ANOVA and post-hoc "Tukey" tests were used to identify the variation within the sample groups. Statistical significance was set at $\mathrm{P}<0.05$.

\section{Results and Discussion}

\section{Proximate analysis of instant mango drinks powder}

The proximate composition of instant mango drinks powder available in local market of Bangladesh is presented in Table 1. The results of moisture content were ranged from 0.21 to $0.25 \%$ for different brand of instant mango drinks powder. The highest value of moisture content $0.25 \%$ was found in brand D of instant mango drinks powder and the lowest value $0.21 \%$ was found for brand $\mathrm{B}$ of instant mango drinks powder. The results of moisture content showed that the moisture content of samples was not significantly different $(\mathrm{p}<0.05)$. Moisture content is an important factor in maintaining product quality because increase moisture facilitates the growth of microbes and ultimately destroy quality of product in a short time. The moisture contents of the instant mango drinks powder were lower than reported by Akhter et al. (2010) for instant mango juice powder and Mohammed et al. (2017) for instant sorrel (Zobo) drink. 
Table 1. Proximate analysis of instant mango drinks powder.

\begin{tabular}{|c|l|l|l|l|l|}
\hline Sample & Moisture (\%) & Ash (\%) & Fiber (\%) & CHO (\%) & Energy (Kcal/100g) \\
\hline A & $0.22 \pm 0.04^{\mathrm{a}}$ & $0.45 \pm 0.02^{\mathrm{b}}$ & $0.20 \pm 0.02^{\mathrm{c}}$ & $99.13 \pm 0.08^{\mathrm{ab}}$ & $396.52 \pm 0.32^{\mathrm{ab}}$ \\
\hline B & $0.21 \pm 0.01^{\mathrm{a}}$ & $0.50 \pm 0.04^{\mathrm{ab}}$ & $0.10 \pm 0.01^{\mathrm{d}}$ & $99.19 \pm 0.06^{\mathrm{a}}$ & $396.76 \pm 0.24^{\mathrm{a}}$ \\
\hline C & $0.24 \pm 0.03^{\mathrm{a}}$ & $0.48 \pm 0.02^{\mathrm{ab}}$ & $0.10 \pm 0.03^{\mathrm{d}}$ & $99.18 \pm 0.08^{\mathrm{a}}$ & $396.72 \pm 0.32^{\mathrm{a}}$ \\
\hline D & $0.25 \pm 0.02^{\mathrm{a}}$ & $0.52 \pm 0.03^{\mathrm{ab}}$ & $0.40 \pm 0.05^{\mathrm{a}}$ & $98.83 \pm 0.10^{\mathrm{c}}$ & $395.32 \pm 0.40^{\mathrm{c}}$ \\
\hline E & $0.23 \pm 0.04^{\mathrm{a}}$ & $0.55 \pm 0.01^{\mathrm{a}}$ & $0.30 \pm 0.01^{\mathrm{b}}$ & $98.92 \pm 0.06^{\mathrm{bc}}$ & $395.68 \pm 0.24^{\mathrm{bc}}$ \\
\hline F & $0.23 \pm 0.02^{\mathrm{a}}$ & $0.46 \pm 0.04^{\mathrm{b}}$ & $0.10 \pm 0.03^{\mathrm{d}}$ & $99.21 \pm 0.09^{\mathrm{a}}$ & $396.84 \pm 0.36^{\mathrm{a}}$ \\
\hline
\end{tabular}

Significant at $P<0.05$; Values followed by different superscript letters denote a significant difference; comparison done across brand. Protein and Fat was not found in any of the instant mango drinks powder.

The highest value of ash content $0.55 \%$ was found in brand $\mathrm{E}$ of instant mango drinks powder and the lowest value $0.45 \%$ was recorded for brand $\mathrm{A}$ of instant mango drinks powder. The results of ash content showed that the ash content of samples was significantly different $(p<0.05)$. The variation of ash content was found due to having different types of minerals in the instant mango drinks powder. The ash contents of the instant mango drinks powder were lower than reported by Akhter et al. (2010) for instant mango juice powder, Mohammed et al. (2017) for instant sorrel (Zobo) drink and Farzana et al. (2017) for vegetable soup powder.

The highest value of fiber content $0.40 \%$ was found in brand D and the lowest value $0.10 \%$ was for brand $\mathrm{B}$. The results of fiber content showed that the samples were significantly different $(p<0.05)$. The results of fiber content of the instant mango drinks powder were close agreement with Farzana et al. (2017) for vegetable soup powder.

The carbohydrate (CHO) content of the six brands of instant mango drinks powder varied significantly. It ranged from 98.83 to $99.21 \%$. The lowest carbohydrate content was found of instant mango drinks powder in brand D (98.83\%), whereas highest amount of instant mango drinks powder in brand F (99.21\%). The carbohydrate content of instant mango drinks powder is excellently high showing that it is a good source of energy. The high carbohydrates content could be due to the addition of nutritive sweetener, sucrose. The carbohydrate contents of the instant mango drinks powder were higher than reported by Mohammed et al. (2017) for instant sorrel (Zobo) drink, Farzana et al. (2017) for vegetable soup powder and Obilana et al. (2018) for instant beverage powder.
In this study, the energy value of the six brands of instant mango drinks powder ranged from 395.32 to 396.84 (Kcal/10og). The highest content was found for the brand F (396.84 $\mathrm{kcal} / 100 g)$, whereas least in the brand D (395.32 $\mathrm{kcal} / 100 \mathrm{~g})$. The results of energy value showed that the samples were significantly different $(p<0.05)$. High amount of carbohydrate in the instant mango drinks powder leads to increase the energy value. The energy value of the instant mango drinks powder was higher than reported by Mohammed et al. (2017) for instant sorrel (Zobo) drink, Farzana et al. (2017) for vegetable soup powder and lower values observed by Obilana et al. (2018) for instant beverage powder.

\section{Mineral and Vitamin-C content of instant mango drinks powder}

Mineral and Vitamin-C content of instant mango drinks powder available in local market of Bangladesh are presented in Table 2. The results of mineral contents were found in all instant mango drinks powder samples in the range as $\mathrm{Na}$ (40.09-52.07) mg/dl, K (0.40-0.50) mg/dl, Ca (1.20-1.90) mg/dl, Cl (1.10-2.00) mg/dl, P (0.44$0.55) \mathrm{mg} / \mathrm{dl}$ and $\mathrm{Fe}(0.10-0.18) \mathrm{mg} / \mathrm{dl}$. In case of mineral content, a one-way ANOVA showed that the instant mango drinks powder samples were significantly different $(\mathrm{p}<0.05)$. The highest value of $\mathrm{Na}, \mathrm{K}, \mathrm{Ca}, \mathrm{Cl}, \mathrm{P}$ and $\mathrm{Fe}$ content was found in brand $\mathrm{E}$. The lowest value of $\mathrm{Na}, \mathrm{Ca}, \mathrm{Cl}, \mathrm{P}$ content was found in brand $\mathrm{A}$ and $\mathrm{K}, \mathrm{Fe}$ content was found in brand $\mathrm{F}$. The mineral content was found due to having different types of additives and salts in the instant mango drinks powder. The sodium and potassium content of the instant mango drinks powder was lower than reported by Farzana et al. (2017) for vegetable soup powder. Obilana et al. (2018) prepared instant beverage powder from extruded malted pearl millet (Babla) reported the calcium content as 32.56 $\mathrm{mg} / 100 \mathrm{~g}$ and the iron content as $7.78 \mathrm{mg} / 100 \mathrm{~g}$.

Table 2. Mineral contents of instant mango drinks powder.

\begin{tabular}{|c|c|c|c|c|c|c|c|}
\hline imple & dl) & $\mathrm{K}(\mathrm{r}$ & $\mathrm{Ca}(\mathrm{n}$ & $\mathrm{l}$ (mg/dl) & $\mathrm{P}(\mathrm{n}$ & $\mathrm{Fe}(\mathrm{mg} / \mathrm{dl})$ & \\
\hline A & $4000+00-f$ & $0.42 \pm$ & $1.20 \pm 0.08^{d}$ & $10 \pm 0.01^{d}$ & $0.44 \pm 0.02^{\mathrm{b}}$ & $0.10 \pm 0.02^{a}$ & \\
\hline B & & & & & & & \\
\hline C & $6^{a}$ & 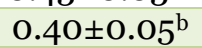 & 1.30 & 1.40 & 0.4 & & \\
\hline I & & 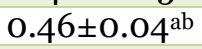 & 1.6 & 1.90 & 0.4 & & 35 \\
\hline & 52. & 0 & $1.90=$ & 2.0 & & & \\
\hline & $1.54 \pm 0.04^{\mathrm{e}}$ & $.40 \pm 0.03^{b}$ & $1.25 \pm 0.02^{\mathrm{cd}}$ & $1.20 \pm 0.09^{\mathrm{d}}$ & $0.45^{ \pm 0.02^{b}}$ & $0.10 \pm 0.01^{a}$ & \pm 0.1 \\
\hline
\end{tabular}

$P<0.05$; Values followed by different superscript letters denote a significant difference; comparison done across brand. 
The results of Vitamin $\mathrm{C}$ content were ranged from $62.45-85.68 \mathrm{mg} / \mathrm{dl}$ for different brand of instant mango drinks powder. The highest value of Vitamin C content $85.68 \mathrm{mg} / \mathrm{dl}$ was found in brand $\mathrm{D}$ and the lowest value $62.45 \mathrm{mg} / \mathrm{dl}$ was for brand $\mathrm{C}$ of instant mango drinks powder. The results of Vitamin $\mathrm{C}$ content showed that the Vitamin $\mathrm{C}$ content of samples was significantly different (p<0.05). Farzana et al. (2017) prepared soup powder from vegetable reported the Vitamin C content as $6.4 \mathrm{mg} / 100 \mathrm{~g}$.

\section{Bioactive compounds of instant mango drinks powder}

The Bioactive compounds of instant mango drinks powder available in local market of Bangladesh are presented in Table 3 . The results of total anthocyanin content (TAC) were ranged from $0.16-0.23 \mathrm{mg} / 100 \mathrm{~g}$ for different brand of instant mango drinks powder. The highest value of total anthocyanin content $0.23 \mathrm{mg} / 100 \mathrm{~g}$ was found in brand $\mathrm{E}$ and the lowest value 0.16 $\mathrm{mg} / 100 \mathrm{~g}$ was for brand A of instant mango drinks powder. The anthocyanin content was found due to the presence of coloring agents in the instant mango drinks powder. The results of anthocyanin content showed that the anthocyanin content of samples was significantly different $(p<0.05)$. The anthocyanin content of the instant mango drinks powder was higher than reported by Akther et al. (2020) for instant mango drink powder.

The results of total flavonoid content (TFC) were ranged from 5.31-2.27 mg QE/10og for different brand of instant mango drinks powder. The highest value of total flavonoid content (5.31 $\pm 0.15 \mathrm{mg} \mathrm{QE} / 100 \mathrm{~g})$ was found in brand $\mathrm{C}$ and the lowest value $(2.27 \pm 0.10 \mathrm{mg} Q \mathrm{QE} / 1 \mathrm{Oog})$ was for brand A of instant mango drinks powder. Due to presence of the flavoring agents in the instant mango drinks powder, total flavonoid content was discovered. The results of flavonoid content showed that the flavonoid content of samples was significantly different $(\mathrm{p}<0.05)$.

The results of total phenolic content (TPC) were ranged from 12.05-21.79 mg GAE/10og for different brand of instant mango drinks powder. The highest value of total phenolic content (21.79 $\pm 0.03 \mathrm{mg} \mathrm{GAE} / 1 \mathrm{Oog})$ was found in brand $\mathrm{B}$ and the lowest value $(12.05 \pm 0.05 \mathrm{mg}$ GAE/10og) was for brand $F$ of instant mango drinks powder. The results of total phenolic content showed that the total phenolic content of samples was significantly different $(\mathrm{p}<0.05)$. Obilana et al. (2018) prepared instant beverage powder from extruded malted pearl millet (Babla) reported the total phenolic content as $1.30 \mu \mathrm{g} / \mathrm{g}$.

Table 3. Bioactive compounds of instant drinks powder.

\begin{tabular}{|c|c|c|c|c|}
\hline Sample & $\begin{array}{c}\text { TAC } \\
(\mathrm{mg} / 100 \mathrm{~g})\end{array}$ & $\begin{array}{c}\text { TFC } \\
(\mathrm{mg} \mathrm{QE} \mathrm{/100g)}\end{array}$ & $\begin{array}{c}\text { TPC } \\
\text { (mg GAE/10og) }\end{array}$ & $\begin{array}{l}\text { Antioxidant Capacity } \\
\text { (mg TE/100g) }\end{array}$ \\
\hline A & $0.16 \pm 0.02^{b}$ & $2.27 \pm 0.10^{\mathrm{d}}$ & $14.62 \pm 0.07^{\mathrm{e}}$ & $23.93 \pm 0.04^{\mathrm{d}}$ \\
\hline B & $0.19 \pm 0.01^{\mathrm{ab}}$ & $5.27 \pm 0.05^{\mathrm{a}}$ & $21.79 \pm 0.03^{\mathrm{a}}$ & $32.69 \pm 0.10^{\mathrm{a}}$ \\
\hline $\mathrm{C}$ & $0.18 \pm 0.03^{\mathrm{ab}}$ & $5.31 \pm 0.15^{\mathrm{a}}$ & $18.81 \pm 0.10^{b}$ & $22.53 \pm 0.07^{\mathrm{e}}$ \\
\hline $\mathrm{D}$ & $0.21 \pm 0.01^{\mathrm{a}}$ & $3 \cdot 39 \pm 0.12^{c}$ & $17.07 \pm 0.02^{c}$ & $32.70 \pm 0.18^{a}$ \\
\hline $\mathrm{E}$ & $0.23 \pm 0.02^{\mathrm{a}}$ & $4.84 \pm 0.13^{b}$ & $15.05 \pm 0.06^{d}$ & $29.5^{1 \pm 0.16^{b}}$ \\
\hline $\mathrm{F}$ & $0.18 \pm 0.00^{a b}$ & $5.17 \pm 0.05^{\mathrm{a}}$ & $12.05^{ \pm 0.05^{\mathrm{f}}}$ & $26.46 \pm 0.30^{c}$ \\
\hline
\end{tabular}

Significant at $P<0.01$; Values followed by different superscript letters denote a significant difference; comparison done across brand.

The results of antioxidant capacity were ranged from 22.53-32.70 $\mathrm{mg} \mathrm{TE} / 100 \mathrm{~g}$ for different brand of instant mango drinks powder. The highest value of antioxidant capacity $(32.70 \pm 0.18$ $\mathrm{mg} \mathrm{TE} / 100 \mathrm{~g}$ ) was found in brand $\mathrm{D}$ and the lowest value $(22.53 \pm 0.07 \mathrm{mg} \mathrm{TE} / 100 \mathrm{~g})$ was for brand $\mathrm{C}$ of instant mango drinks powder. Due to presence of the different types of food acid and acid regulator in the instant mango drinks powder, the antioxidant capacity was detected. The results of antioxidant capacity showed that the antioxidant capacity of samples was significantly different $(\mathrm{p}<0.05)$. Obilana et al. (2018) prepared instant beverage powder from extruded malted pearl millet (Babla) reported the antioxidant capacity as $1.78 \mu$ mole TE/g. The results of antioxidant capacity were close agreement with Akther et al. (2020) for instant mango drink powder.

\section{Conclusion}

Instant mango drinks powder provides instant energy, and is well known due to its excellent taste, purity, accurate composition, safe consumption and long shelf life. It also provides instant rehydration and instant freshness. Mango drinks powder includes flavors, colors with minerals and vitamins. This study shows the quality evaluation of instant mango drinks powders available in local market. Instant mango drinks powder samples were a good source of vitamin-C, carbohydrate and high energy. 


\section{References}

Akhter, S., Abid, H., Yasmin, A. and Masood, S. 2010. Preparation and evaluation of physical and chemical characteristics of mango juice powder. Pakistan J. Biochem. Mole. Biol. 43(2): 58-60.

Akpakpan, A. and Akpabio, U. 2012. Evaluation of proximate composition, mineral element and anti-nutrient in almond (Terminalia catappa) seeds. Res. J. Appl. Sci. 7(9-12): 489-493.

Akther, S., Alim, M.A., Badsha, M.R., Matin, A., Ahmad, M. and Hoque, S.M.Z. 2020. Formulation and quality evaluation of instant mango drinks powder. Food Res. 4(4): 1287-1296.

https://doi.org/10.26656/fr.2017.4(4).077

AOAC. 2016. Official Methods of Analysis. 20 ${ }^{\text {th }}$ Edition, Association of Official Analytical Chemists, Washington, DC, USA.

Azlim Almey, A.A., Ahmed Jalal Khan, C., Syed Zahir, I., Mustapha Suleiman, K., Aisyah, M.R. and Kamarul Rahim, K. 2010. Total phenolic content and primary antioxidant activity of methanolic and ethanolic extracts of aromatic plants' leaves. Int. Food Res. J. 17(4): 1077-1084.

Chang, C.C., Yang, M.H., Wen, H.M. and Chern, J.C. 2002. Estimation of total flavonoid content in propolis by two complementary colorimetric methods. J. Food Drug Anal. 10(3): 178-182.

https://doi.org/10.38212/2224-6614.2748

Chen, C.C., Mergens, W.J. and Milbank, M.C. 2000. Vitamin powders for beverage applications and method of making, US6162474A. United States. Google Patents.

Farzana, T., Mohajan, S., Saha, T., Hossain, M.N. and Haque, M.Z. 2017. Formulation and nutritional evaluation of a healthy vegetable soup powder supplemented with soy flour, mushroom, and moringa leaf. Food Sci. Nutri. 5(4): 911-920.

https://doi.org/10.1002/fsn3.476

Mahendran, T. 2011. Physico-chemical properties and sensory characteristics of dehydrated guava concentrate: effect of drying method and maltodextrin concentration. Trop. Agric. Res. Ext. 13(2): 48-54.

https://doi.org/10.4038/tare.v13i2.3138

McIntyre, A. 2000. Drink to your health. $1^{\text {st }}$ edition, Simon and Schuster, New York. pp. 128-132.

Mohammed, S., Gimba, I. and Bahago, E. 2017. Production and quality evaluation of instant sorrel (zobo) drink produced by infusion, dehydration and size reduction methods. $J$. Nutri. Health Sci. 4(2): 1-10.

https://doi.org/10.15744/2393-9060.4.205

Mustafa, F. and Medeiros, D. 1985. Proximate composition, mineral content and fatty acids of catfish (Ictalurus punctatus, Rafinesque) for different seasons and cooking methods. J. Food Sci. 5O(3): 585-588. https://doi.org/10.1111/j.1365-2621.1985.tb13749.x

Najwa, F.R. and Azrina, A. 2017. Comparison of vitamin $\mathrm{C}$ content in citrus fruits by titration and high-performance liquid chromatography (HPLC) methods. Int. Food Res. J. 24(2): 726-733.

Obilana, A.O., Odhav, B. and Jideani, V.A. 2018. Nutritional, biochemical and sensory properties of instant beverage powder made from two different varieties of pearl millet. Food Nutri. Res. 62: 1524. https://doi.org/10.29219/fnr.v62.1524

Pap, L. 1995. Production of pure vegetable juice powders of full biological value. Fruit Proc. 3: $55-60$.

Saxena, R. and Arora, V. 1997. Consumers of processed fruit and vegetable products: an analysis of buying behaviour. Indian Food Industry. 16: 25-36.

Thind, K., Grewal, K. and Bakshi, A. 2002. Method of preparation and keeping quality of reconstituted skim milk-based mango beverage. Bev. Food World. 29(8): 60-62.

Unal, K., Susanti, D. and Taher, M. 2014. Polyphenol content and antioxidant capacity in organically and conventionally grown vegetables. J. Coastal Life Medi. 2(11): 864871. 